\title{
INVESTIGASI ATAS PERILAKU KONSUMEN MUSIK INDONESIA DALAM MENGGUNAKAN PRODUK MUSIK BAJAKAN
}

\author{
Sony Kusumasondjaja dan Nazar Karami \\ Fakultas Ekonomi dan Bisnis Universitas Airlangga \\ Email: s_kusumasondjaja@yahoo.com
}

\begin{abstract}
Abstraksi
The increasing adoption of pirated music products intesifies the needs to understand factors influecing consumers to buy pirated music products. This study examines the impact of attribute satisfaction, singer idolization, prosecution risk, social consensus, maginitude of consequences, and proximity on consumer attitude toward pirated music products and their intention to buy the products. Data was collected through online survey distributed on Facebook involving pirated music product consumers. Findings suggest that attribute satisfaction, maginitude of consequences, and proximity affect attitude toward the pirated music products, while attribute satisfaction, prosecution risk, social consensus, and maginitude of consequences influence consumer intention to buy pirated products. Research contributions and implications are discussed.
\end{abstract}

Kata Kunci: kepuasan, risiko, konsensus sosial, sikap, niat konsumen, online marketing

\section{PENDAHULUAN}

Semakin meningkatnya pendengar musik direspon oleh pelaku industri hiburan dengan berbagai cara. Industri hiburan di televisi, misalnya, menyambutnya dengan menayangkan serangkaian program musik dengan konsep yang berbeda-beda yang terbukti sukses menarik perhatian audiens, mulai dari konsep akustik seperti MTV Unplugged atau Soul Train, konsep pencarian bakat seperti American Idol, X Factor, atau The Voice dan yang lainnya. Di Indonesia, tayangan musik Dahsyat, Inbox, X Factor Indonesia, atau Indonesian Idol juga dikenal sebagai program TV yang memperoleh rating yang sangat baik. Tingginya antusiasme konsumen dalam menyaksikan acara musik di televisi merupakan salah satu indikasi bahwa produk musik tetap dibutuhkan oleh konsumen.

Sayangnya, kesuksesan berbagai tayangan musik di televisi tidak nampak pada penjualan fisik rekaman musik dalam bentuk kaset dan CD yang terus menerus menurun. Data yang dirilis Asosiasi Industri Rekaman Indonesia (ASIRI) menjelaskan bahwa pada tahun 2006 menurun $21 \%$ dibandingkan dengan pada 2005. Terbukti, album yang terjual pada 2006 sebanyak 24 juta keping. Namun terus menurun pada 2007, yakni 19 juta keping. Sedangkan pada 2008 hanya 15 juta keping album yang terjual. Kecenderungan yang terus menurun ini terkesan kontradiktif dengan banyaknya acara musik di televisi serta ramainya sambutan masyarakat pada tayangan musik tersebut.

Menariknya, penurunan jumlah penjualan fisik rekaman musik di Indonesia seperti yang disebutkan di atas ternyata terjadi juga pada penjualan rekaman musik musisi 


\section{Sony Kusumasondjaja \\ Nazar Kharisma}

internasional di seluruh dunia. Artinya, masalah ini bukanlah masalah nasional Indonesia melainkan masalah global. Data menjelaskan bahwa dalam enam tahun terakhir, penurunan nilai penjualan fisik rekaman musik yang terjadi di seluruh dunia mencapai angka 40 persen. Berdasarkan data eMarketer angka penjualan fisik produk rekaman musik pada 2006 nilainya masih mencapai 33,1 miliar USD. Setahun kemudian nilainya turun menjadi 30,6 miliar USD dan terus merosot pada tahun-tahun sesudahnya menjadi 27,5 miliar USD (2008), 24,6 miliar USD (2009), 22,2 miliar USD (2010), dan 19,9 miliar USD pada 2011 (www.grabstats.com :2012). Tak mengherankan bila majalah musik terkenal dunia The Rolling Stones menyebut dekade ini sebagai era terburuk untuk industri musik dunia (www.kompas.com).

Fenomena menurunnya angka penjualan fisik produk musik di Indonesia diduga disebabkan oleh beberapa faktor. Munculnya produk yang menawarkan cara-cara baru untuk menikmati musik juga berperan dalam menggeser preferensi konsumen. Misalnya, kemunculan iTunes yang memungkinkan konsumen untuk mendengarkan lagu-lagu secara mobile dari telepon genggam atau iPod dengan cara mengunduhnya secara murah, online, dan legal. Hal ini membuat banyak konsumen beramai-ramai memenuhi keinginan mereka atas lagu-lagu baru dengan cara mengunduhnya dari iTunes. Selain menawarkan kepraktisan, iTunes juga menawarkan produk musik rekaman legal secara satuan - tidak secara paket beberapa lagu yang dikemas dalam bentuk album - dengan harga yang cukup murah. Fenomena iTunes membuat sebagian besar konsumen muda beralih dari membeli satu album menjadi membeli lagu secara eceran di media tersebut.

Untuk membeli lagu di iTunes caranya cukup sederhana, hal pertama yang dilakukan adalah mendownload terlebih dahulu aplikasi iTunes. Kemudian ikuti pembuatan akun iTunes. Langkah selanjutnya, mengisi saldo akun iTunes kita dengan cara membeli voucher (giftcard) atau dengan mendaftarkan rekening kartu kredit. Setelah itu, kita dapat membeli lagu sesuai keinginan. Berdasarkan pengamatan detik iNET, lagu-lagu lokal dan mancanegara tersedia di iTunes dengan harga bervariasi mulai dari Rp 5.000 - Rp 7.000 dan untuk harga satu album berkisar antara Rp 45.000 - Rp 65.000. Hal tersebut mengakibatkan penjualan lagu di media iTunes mencapai angka \$1,7 miliar dalam kurun waktu 10 tahun hingga akhir kuartal dua 2012 lalu, menurut majalah musik dunia The Rolling Stones yang dikutip Tekno Liputan6.com.

Faktor lain yang juga diduga berperan besar dalam penurunan angka penjualan fisik produk musik, baik di dunia musik internasional dan di pasar musik Indonesia, adalah semakin merajalelanya pembajakan produk musik. Semakin banyak dan murah produk CD bajakan membuat CD resmi tidak menjadi pilihan menarik bagi konsumen.

Pembajakan musik di Indonesia terpusat di beberapa lokasi di kota besar, seperti Jakarta atau Surabaya. Area penjualan CD/DVD Glodok, Tamansari, Jakarta Barat merupakan pusat distribusi CD bajakan terbesar di Indonesia. Pihak pabrikan tidak perlu membayar artis, pencipta lagu, pemusik serta royaltinya. Para pabrik pembajak hanya bermodal kepingan CD kosong, cetak label untuk cover, dan mesin pengganda. Dalam satu hari, pabrik pembajak bisa mencetak 200.000 keping yang kemudian disalurkan kepada distributor dengan harga jual sekitar Rp 2000/keping. Di tingkat eceran, harga CD bajakan sekitar Rp 5000/keping. Di sisi lain, data yang dihimpun ASIRI pada Tabel 1.1. menunjukan bahwa masih ada konsumen musik di Indonesia yang membeli produk musik yang asli dan legal. Fenomena yang dijelaskan di atas menunjukkan dinamika pada industri musik Indonesia yang menarik untuk dikaji lebih lanjut.

Beberapa penelitian terdahulu menemukan bahwa ada beragam penyebab mengapa konsumen lebih memilih untuk mengkonsumsi produk musik bajakan. Phau dan $\mathrm{Ng}$ (2010) menemukan bahwa kecenderungan konsumen akan produk dengan harga lebih murah berpengaruh terhadap sikap terhadap produk lagu bajakan dan niat konsumen mengkonsumsi lagu bajakan, meskipun produk bajakan tersebut tidak memiliki kualitas yang tidak terlalu baik. Meskipun demikian, konsumen musik di Indonesia mengetahui bahwa harga CD lagu resmi bisa 15 kali lebih mahal daripada versi bajakannya. Dan karena alasan tersebut, konsumen musik Indonesia nampaknya tidak terlalu peduli pada keterbatasan 
kualitas produk CD lagu bajakan tersebut dan merasa puas dengan apa yang atributatribut yang melekat pada CD bajakan tersebut.

Hal ini yang mendorong banyak perusahaan rekaman dan manajemen artis untuk membentuk klub penggemar untuk mengurangi pembajakan pada lagu atau album artis tersebut. Menurut penelitian Chiou, Huang, dan Lee (2005) kecintaan pada penyanyi atau musisi tertentu membuat konsumen tidak berniat untuk mengkonsumsi versi bajakan lagu karya penyanyi atau musisi kesayangan mereka. Namun, temuan Puspitha (2009) menegaskan bahwa konsumen menunjukkan kecintaan terhadap artis yang mereka sayangi dengan cara membeli sebanyak mungkin lagu karya mereka, meskipun lagu yang dibeli tersebut adalah versi bajakan.

Pembelian musik bajakan tentu saja memiliki dampak negatif terhadap beberapa pihak yang berkaitan langsung seperti penyanyi, perusahaan label rekaman yang akan mengalami kerugian finansial secara langsung (Chiou, Huang, \& Lee, 2005). Hal ini seperti yang dilakukan musisi Rhoma Irama beserta artis penyanyi lainnya yang tergabung dalam Persatuan Artis Musik Melayu Dangdut Indonesia (PAMMI) melakukan aksi pembakaran CD bajakan sebagai bentuk perlawanan terhadap praktek pembajakan yang terjadi di Indonesia yang peredarannya sudah mencapai $90 \%$ dari produk aslinya (viva.co.id). Lebih jauh lagi, maraknya pembajakan musik dapat berakibat negatif pada diri konsumen sendiri. Tahun 1985 Bob Geldof, musisi Amerika Serikat mengecam pembajakan kaset yang terjadi di Indonesia dalam forum internasional agar turis mancanegara tidak datang ke negara ini lagi. Hal itu dikarenakan pembajakan lagu-lagu pada konser Live Aid yang bertujuan menggalang dana untuk masyarakat Ethiopia (Bertens, 2000).

Sebagian besar konsumen musik di Indonesia paham bahwa membeli produk bajakan adalah tindakan melanggar hukum. Pada kenyataannya, yang terlihat di lapangan menunjukkan bahwa konsumen tidak terlalu mempedulikan ancaman hukuman pidana yang dapat mereka terima karena membeli produk musik bajakan. Fenomena ini merupakan indikasi bahwa konsumen menganggap bahwa mengkonsumsi lagu bajakan mengandung risiko hukum yang rendah. Apalagi sepertinya norma-norma dan konsensus sosial yang berlaku di masyarakat juga tidak terlalu peduli dengan aturan yang melarang konsumen membeli dan mengkonsumsi produk bajakan.

Penelitian ini bertujuan mengamati sikap dan perilaku konsumen musik Indonesia menggunakan produk musik bajakan dan faktor-faktor yang mempengaruhinya. Mengadaptasi dari studi yang dilakukan Chiou, Huang, dan Lee (2005), penelitian ini mengukur pengaruh enam faktor dalam pembentukan sikap konsumen terhadap produk lagu bajakan dan niat konsumen membeli musik bajakan. Keenam faktor tersebut adalah kepuasan konsumen atas atribut yang melekat pada CD resmi (attribute satisfaction), kecintaan pada musisi yang karyanya dibajak (singer idolization), resiko hukum atas tindakan mengkonsumsi CD lagu bajakan (prosecution risk), konsensus masyarakat (social consensus), pengaruh pembajakan lagu pada musisi (magnitude of consequence) dan pengaruhnya pada diri konsumen sendiri (proximity). Berdasarkan latar belakang yang disampaikan di atas, penelitian ini berfokus pada pembahasan topik "Investigasi Atas Perilaku Konsumen Musik Indonesia Dalam Menggunakan Produk Musik Bajakan".

Berdasarkan penjelasan latar belakang, maka permasalahan yang dijawab pada penelitian ini adalah (1) apakah attribute satisfaction, singer idolization, prosecution risk, social consensus,magnitude of consequence dan proximity berpengaruh pada sikap konsumen terhadap produk musik bajakan?, dan (2) apakah singer idolization, proximity dan sikap terhadap lagu bajakan berpengaruh pada niat membeli produk musik bajakan?

\section{LANDASAN TEORI DAN PENGEMBANGAN HIPOTESIS}

\section{Pengambilan Keputusan Konsumen}




\section{Sony Kusumasondjaja \\ Nazar Kharisma}

Keputusan (decision) menurut Peter dan Olson (2005:165) melibatkan pilihan antara dua atau lebih alternatif tindakan atau perilaku. Sedangkan pengambilan keputusan konsumen adalah proses pengintegrasian yang mengkombinasikan pengetahuan untuk mengevaluasi dua atau lebih perilaku alternatif dan akhirnya memilih diantaranya. Hasil dari proses pengintegrasian ini adalah suatu pilihan, yang disajikan secara kognitif keinginan berperilaku (behavioral intention). Model pengambilan keputusan konsumen menimbulkan tiga ciri yaitu interpretasi, integrasi, dan pengetahuan produk dalam ingatan. Proses interpretasi mensyaratkan penemuan pada informasi dan melibatkan dua proses kognitif terkait yaitu perhatian dan pemahaman. Perhatian mengatur bagaimana konsumen memilih informasi mana yang harus diterjemahkan dan informasi mana yang harus diabaikan. Pemahaman mengacu pada bagaimana konsumen menetapkan arti subjektif dari informasi dan oleh karena itu menciptakan pengetahuan serta kepercayaan personal.

Pengetahuan (knowledge), arti (meaning), dan kepercayaan (beliefs) dapat saling dipertukarkan untuk mengacu pada berbagai tipe interpretasi personal atau subjektif yang dihasilkan oleh proses interpretasi. Pengetahuan, arti dan kepercayaan dapat disimpan dalam ingatan yang kemudian dapat dipanggil kembali dari ingatan (diaktifkan) dan digunakan dalam proses integrasi. Proses integrasi (integration process) menyangkut bagaimana konsumen mengkombinasikan berbagai jenis pengetahuan untuk membentuk evaluasi produk, objek lain serta perilaku, dan pilihan di antara beberapa perilaku alternatif seperti pembelian. Pengetahuan produk dan keterlibatan (product knowledge and involvement) mengacu pada berbagai jenis pengetahuan, arti dan kepercayaan yang direkam dalam ingatan konsumen. Pengetahuan produk yang diambil dari ingatan memiliki potensi untuk mempengaruhi interpretasi dan integrasi proses. Keterlibatan produk mengacu pada pengetahuan konsumen tentang relevansi personal suatu produk dalam hidupnya.

\section{Produk llegal}

Produk ilegal menurut Kotler dan Keller (2009), merupakan salah satu strategi pengikut pasar yang meniru bulat-bulat produk dan kemasan pemimpin serta menjualnya di pasar gelap atau melalui penyalur yang memiliki reputasi yang buruk. Jika mengacu pada kedua premis di atas, dapat disimpulkan bahwa produk ilegal tidak sesuai dengan konsep pemasaran. Hal ini disebabkan produk bajakan tidak menyampaikan nilai kepada konsumen dengan cara yang baik, yang menguntungkan bagi semua pihak yang berkepentingan. Karena produk bajakan dijual dan didistribusikan melalui cara ilegal yang melanggar norma hukum yang telah disepakati.

Lai dan Zaichkowsky (1999) mendefinisikan counterfeit sebagai produk yang dibuat dengan ilegal yang menyerupai barang aslinya, namun biasanya berkualitas rendah dalam tampilannyadan ketahanannya (durability). Produk counterfeit merupakan tiruan dari merek yang sudah ada (Cordell, Wongtada dan Kieschnick :1996), dibuat dengan sangat mirip atau identik dengan benda aslinya. Dalam dunia internasional WTO berperan dalam koordinasi antar negara dalam memerangi pembajakan (Hidayat dan Mizerski: 2005). Di Indonesia sendiri mulai tahun 2000 masalah pembajakan telah diatur melalui UU HKI. Dari segi keuntungan, perusahaan yang melakukan pembajakan mendapatkan tidak lebih tinggi dari produsen pemimpin. Sehingga sebesar apapun laba yang diperoleh, pembajak tidak akan mampu menjadi pemimpin pasar (Levitt, 1966).

Counterfeit merupakan masalah yang signifikan dan berkembang di seluruh dunia, baik terjadi di negara yang berkembang maupun di negara yang sudah maju dan merupakan ancaman tradisional bagi merek dagang dan hak paten (Matos et al. :2007). Menurut Cordell et al. (2005), setiap produksi produk dengan karakteristik khusus yang dilindungi oleh IPR (Intellectual Property Rights), yaitu merek dagang, paten dan hak cipta, merupak produk counterfeit. Lai dan Zaichkowski (1999) membagi pelanggaran IPR dalam empat kategori, yaitu counterfeiting, piracy, merek imitasi (brand imitation) dan area abuabu (grey area). Selanjutnya Lai dan Zaichkowski menjelaskan, suatu benda dikatakan counterfeit jika $100 \%$ tiruan dan biasanya memiliki kualitas yang buruk jika dibandingkan aslinya. Definisi untuk piracy sendiri tidak jauh berbeda, yang membedakan dengan counterfeit, pelanggan produk piracy secara sadar mencari produk dan membeli produk 


\section{Jurnal Manajemen Teori dan Terapan \\ Tahun 6. No. 3, Desember 2013}

palsu. Produk piracy umumnya memiliki desain, kualitas dan fitur-fitur yang sangat jelas berbeda dengan produk aslinya. Contoh dari produk piracy adalah piranti lunak komputer (sotware) dan alat-alat elektronik yang dijual dengan harga yang jauh lebih rendah dibanding produk aslinya. Untuk merek imitasi, adalah produk atau jasa yang memiliki kesamaan tidak identik pada nama, bentuk, format yang bertujuan untuk diterima secara luas oleh konsumen. Sebagai contoh adala biskuit Rodeo yang merupakan merek imitasi dari produk biskuit Oreo. Lain halnya dengan area abu-abu (grey area). Gray area terjadi ketika pabrik melakukan poduksi melebihi yang dibutuhkan dan kemudian menjualnya secara ilegal.

Dalam penelitian yang dilakukan oleh Chiou, Huang dan Lee (2005), terdapat enam faktor yang mempengaruhi sikap konsumen atas produk musik bajakan. Keenam faktor tersebut adalah attribute satisfaction, singer idolization, prosecution risk, social consensus, magnitude of consequence dan proximity.

\section{Attribute satisfaction}

Kepuasan yang melekat pada CD asli. Konsumen saat ini memprediksi performance (kualitas kinerja) yang akan datang berdasarkan performance CD asli yang ada sekarang (Bolton dan Lemon, 1999). Karena itu, pelanggan yang puas lebih cenderung untuk membeli produk / jasa yang sama berulang kali, yang akan berdampak penolakan penawaran yang ada dari pesaing, dan akan menghasilkan hal yang positif dari mulut ke mulut (Bolton, 1998). Kepuasan adalah keadaan sementara untuk pengalaman pada satu-waktu atau berulang kali yang mencerminkan bagaimana produk atau jasa telah memenuhi tujuan. Hal ini adalah benih untuk preferensi abadi (Oliver, 1999).

\section{Singer idolization}

Menurut Raviv et al. (1996), untuk menjadi penggemar setia, konsumen harus berperilaku dengan cara membeli album asli, mengumpulkan merchandise, menghadiri acara-acara terkait, dan menulis surat. Semua perilaku tersebut dapat menunjukkan spirit di antara para anggota dari komunitas penggemar. Karena komunitas grup diberikannya pengaruh signifikan terhadap anggotanya, perilaku pembajakan musik terhadap produk musik dari penyanyi / grup band idola yang tidak akan ditoleransi antara kelompok penggemar (Einerson, 1998; Raviv et al, 1996). Hal ini yang menjadi spirit penggemar dapat tumpah ke sikap umum mereka pembajakan musik. Namun, mereka mungkin lebih terhadap pembajakan musik perilaku karena perilaku kegemaran mereka terhadap penyanyi idola mereka / grup band. Mereka percaya bahwa perkembangan perilaku pembajakan musik dalam masyarakat dapat akhirnya menyakiti penyanyi / band idola mereka. Idolization sebagian besar didasarkan pada dua komponen: pendewaan dan pemodelan (Raviv et al, 1996). Pendewaan mengacu pada kekaguman yang luar biasa dan penghormatan seorang idola. Pemodelan mengacu pada keinginan untuk menjadi seperti idola. Oleh karena itu, idolization tidak hanya akan mempengaruhi keseluruhan sikap konsumen terhadap pembajakan musik, tetapi juga secara langsung mempengaruhi niat mereka terhadap pembajakan musik idola mereka penyanyi/grup band. Selain itu, musik penyanyi /grup band idola sangat penting untuk penggemar, perasaan kedekatan juga dapat secara langsung mempengaruhi niat mereka terhadap pembajakan musik idola mereka.

\section{Perceived prosecution risk}

Fraedrich dan Ferrell (1992) mengukur dampak risiko yang dirasakan dan filsafat moral pada pembuatan keputusan secara etis. Hal ini diringkas enam aspek risiko, yaitu keuangan, kinerja, fisik, psikologis, sosial, dan risiko secara keseluruhan, dari literatur masa lalu. Menurut Tan (2002), keuangan, kinerja, sosial, dan penuntutan adalah aspek yang paling penting dari risiko yang berlaku di konteks pembajakan perangkat lunak. Begitu pun pada pembajakan musik, berfokus pada efek risiko penuntutan sikap pembajakan untuk alasan berikut. Pertama, karenabiaya pembelian CD musik bajakan tidak sangat mahal, risiko keuangan sangat rendah. Kedua, seperti yang disebutkan, dengan munculnya era 


\section{Sony Kusumasondjaja \\ Nazar Kharisma}

digital, performance CD bajakan biasanya dapat memiliki kualitas sebagus asli satu. Oleh karena itu, risiko performance tidak sangat kuat. Akhirnya, konsep risiko sosial sangat mirip dengan konsep konsensus sosial di literatur intensitas moral. Untuk mempermudah, konsep risiko pengaruh sosial akan dimasukkan di bagian berikutnya tentang intensitas moral. Hampir sama dengan pendapat Tan (2002), Chiou, Huang dan Lee (2005) mengusulkan bahwa risiko sangat penting dalam mempengaruhi sikap pembajakan konsumen. Perilaku membeli $C D$ musik bajakan adalah melanggar hak cipta. Konsumen akan menanggung risiko tindakan hukum oleh pemegang hak cipta.

\section{Social consensus, magnitude of consequences dan perceived proximity}

Permasalahan moral yang disebabkan pembajakan musik adalah keputusan untuk membeli produk musik bajakan. Hal ini yang menjadi dilema sosial apakah etis jika konsumen memutuskan untuk embeli produk musik bajakan tersebut. Menurut Rest (1979) apabila semakin tinggi tingkat seseorang dalam melakukan penilaian moral, maka akan semakin kecil kemungkinan seseorang akan menyetujui atau terlibat dalam perilaku pembajakan. Menurut Jones (1991), kewajiban untuk bertindak dalam situasi, atau perintah moral, ini terkait dengan keseriusan konsekuensi etis yang akan mengalir dari situasi. Konsep moral intensitas multidimensi. Komponen-komponennya antara lain: (1) magnitude of consequences (besarnya konsekuensi), yaitu didefinisikan sebagai kerugian akibat perilaku atau perbuatan untuk korban tindakan moral, (2) social consensus (konsensus sosial), digambarkan sebagai tingkat kesepakatan sosial tentang kebaikan atau kejahatan tindakan yang diusulkan, (3) the probability of effect (probabilitas efek), didefinisikan sebagai fungsi bersama kemungkinan terjadinya suatu perbuatan dan konsekuensi yang diharapkan dari tindakan itu, (4) temporal immediacy (kedekatan sementara), yang didefinisikan sebagai panjang waktu antara tindakan dan etika yang konsekuensi, (5) proximity (kedekatan), yang memanfaatkan perasaan kedekatan (sosial, budaya, psikologis, atau) fisik yang pelaku moral memiliki untuk korban tindakan kejahatan tersebut, dan (6) concentration of effect (konsentrasi efek), sejauh mana biaya atau manfaat dari tindakan itu berlaku hanya beberapa orang. Menurut Jones (1991), enam dimensi intensitas moral adalah karakteristik masalah di bawah pertimbangan, bukan karakteristik individu pembuat keputusan atau konteks organisasi atau lingkungan. Di antara enam komponen, magnitude of consequences (Kwong et al., 2003; Morris dan McDonald, 1995; Tan, 2002; Weber, 1993) dan social consensus (Jones dan Huber, 1992; Morris dan McDonald, 1995; Tan, 2002; Weber, 1993) terus-menerus ditemukan memiliki efek signifikan pada penilaian moral individu. Selain itu, proximity ditemukan memiliki efek hanya dalam beberapa situasi moral (Chia dan Mee, 2000; Morris dan McDonald, 1995), dimensi adalah sangat berkaitan dengan topik penelitian ini. Bagi kebanyakan orang, musik adalah bagian penting dari kehidupan. Runtuhnya industri musik akan secara signifikan mempengaruhi kehidupan individu. Oleh karena itu, Chiou, Huang dan Lee (2005) menyatakan bahwa perasaan kedekatan pelaku moral terhadap korban pembajakan akan sangat kuat untuk objek penelitian.

\section{Sikap}

Menurut Kotler dan Keller (2012:190) merumuskan sikap sebagai evaluasi, perasaan emosional, dan tendensi tindakan yang disukai atau tidak disukai seseorang terhadap objek atau ide. Sikap akan menyebabkan seseorang berperilaku konsisten terhadap objek yang serupa. Sikap menurut Schiffman dan Kanuk (2004:253) adalah suatu cara individual untuk berperilaku dengan adanya suatu pembelajaran yang ia terima untuk memberikan tanggapan pada suatu objek tertentu. Individu akan memberi tanggapan tentang apa saja yang diterima begitu pula ketika melihat sesuatu maka akan bersikap terhadap sesuatu tersebut. Sikap berguna bagi pemasaran dalam banyak cara sehingga sering digunakan untuk menilai keefektifan kegiatan pemasaran. Dalam pandangan pengambilan keputusan konsumen, sikap akan mendorong seseorang pada sebuah keputusan pembelian. Sikap dapat pula membantu mengevaluasi tindakan pemasaran sebelum dilaksanakan dalam pasar. Sikap konsumen terhadap objek atau ide akan membimbing pada evaluasi penting, perasaan emosional, dan perilaku (Schiffman dan Kanuk, 2004:254). 


\section{Jurnal Manajemen Teori dan Terapan \\ Tahun 6. No. 3, Desember 2013}

Sikap menurut Assael (1995:266), merupakan perasaan positif atau negatif terhadap suatu produk yang merupakan hasil proses pembelajaran serta mempunyai sifat terus menerus dan akan mengarahkan seseorang pada perilaku yang spesifik. Situasi dimana konsumen mencari cara untuk memecahkan persoalannya dalam pemenuhan kebutuhannya, mereka akan mencari cara untuk memecahkan persoalannya dalam pemenuhan kebutuhannya, mereka akan senantiasa membentuk sikap (positif atau negatif) tentang produk atas dasar informasi yang telah diterimanya dan cognitive (knowledge dan belief) mereka sendiri (Schiffman dan Kanuk, 2004:233).

Sikap terdiri dari tiga komponen penting, yaitu komponen kognitif (cognitive component), komponen afektif (affective component), dan komponen konatif (conative component), yang disebut tricomponent attitude model (Schiffman dan Kanuk, 2004:256). Komponen pertama adalah kognisi, yaitu pengetahuan dan persepsi yang didapat dari kombinasi antara pengalaman dari sikap terdahulu dan informasi yang diperoleh dari berbagai sumber. Pengetahuan dan pengalaman tersebut diperoleh dari bentuk kepercayaan (beliefs), dimana konsumen percaya bahwa sikap memiliki berbagai atribu dan perilaku tertentu yang akan mengarah pada hasil tertentu pula. Kedua, afeksi adalah emosi atau perasaan dari konsumen tentang produk dan merek. Emosi dan perasaaan tersebut seringkali diperlakukan oleh para peneliti sebagai evaluasi dasar, maksudnya adalah emosi dan perasaan tersebut merupakan penilaian umum seseorang terhadap sesuatu. Dan komponen ketiga adalah konatif yang berkaitan dengan kecenderungan seseorang untuk bertindak secara khusus terhadap sesuatu.

Ajzen (1988) mendefinisikan sikap sebagai predisposisi yang dipelajari individu untuk memberikan respon suka atau tidak suka secara konsisten terhadap objek sikap, dimana objek tersebut bisa berupa orang, peristiwa, barang, perusahaan, dan juga merek. Pada akhirnya, sikap untuk bertindak berasal dari tingkat respon suka atau tidak suka seseorang yang merupakan hasil dari proses evaluasi atau penilaian terhadap perilaku tersebut, yang biasanya menjadi penentu utama seseorang untuk niat berperilaku (Fishbein dan Ajzen, 1980).

\section{Niat Konsumen Berperilaku}

Perilaku seseorang ditentukan oleh adanya niat atau keinginan untuk melakukan sesuatu atau yang bersifat behavioral intention (Peter dan Olson, 2005:135). Memiliki sikap favorable atau unfavorable terhadap suatu produk tidak berarti konsumen akan melakukan setiap perilaku favorable atau unfavorable terhadap produk tersebut. Menurut Ajzen dan Fishbein (1977) dalam Theory of Reasoned Action, konsumen secara sadar mempertimbangkan perilaku-perilaku alternatif dan memilih satu yang mengarah pada konsekuensi yang paling diinginkan. Hasil dari proses memilih ini adalah niat untuk melakukan perilaku yang sebenarnya. Apabila niat yang dimiliki oleh konsumen tersebut kuat, maka dia akan berupaya untuk menempuh berbagai cara untuk menunjukan perilakunya demi mencapai tujuan dalam memenuhi niatnya. Sebaliknya, apabila niat yang dimiliki oleh konsumen tersebut lemah, maka dia akan membatalkan dan menggagalkan usahanya sebagai bentuk perilaku demi memenuhi niatnya.

Niat atas suatu perilaku (behavioral intentions) merupakan prediktor terbaik dalam memprediksi perilaku seseorang (Hawkins et al, 2007:516). Niat (intention) merupakan keinginan konsumen untuk berperilaku menurut cara tertentu dalam rangka memiliki, membuang dan menggunakan produk atau jasa. Jadi, konsumen dapat membentuk keinginan untuk mencari informasi, memberitahukan orang lain tentang pengalamannya tentang sebuah produk, membeli produk atau jasa tertentu, atau membuang produk dengan cara tertentu (Mowen dan Minor, 2002:322). Schiffman dan Kanuk (2004:238) mengungkapkan bahwa niat beli (memilih) digunakan untuk mengukur keinginan berperilaku untuk membeli dengan skala dari "pasti membeli" hingga "pasti tidak kembali".

\section{Pengembangan Hipotesis}




\section{Sony Kusumasondjaja \\ Nazar Kharisma}

Atribut-atribut kepuasan yang melekat pada CD asli diyakini Chiou, Huang, dan Lee (2005) tidak mempengaruhi sikap konsumen untuk tetap mengkonsumsi produk musik asli tersebut. Ditemukan bahwa konsumen tidak mempedulikan atribut kepuasan yang melekat pada produk musik bajakan. Meski pun, atribut kepuasan tersebut meliputi kualitas suara, kemasan produk, dan awetnya barang bajakan tersebut. Phau dan Ng (2010) menemukan bahwa kecenderungan konsumen akan produk dengan harga lebih murah yang mempengaruhi sikap konsumen terhadap produk lagu bajakan dan niat untuk mengkonsumsi dan membeli lagu bajakan. Berdasarkan penjelasan ini, diajukan hipotesis berikut ini:

\section{H1 : $\quad$ Attribute satisfaction pada CD bajakan berpengaruh positif terhadap sikap} atas produk musik bajakan

Seorang penggemar biasanya menunjukan perilaku memujanya dengan cara membeli album yang asli, mengumpulkan benda-benda dari idolanya, hadir di setiap konser atau acara yang berkaitan dengan idolanya dan menulis pesan untuk idolanya tersebut (Raviv et al., 1996). Perilaku mengidolakan penyanyi atau sebuah grup band diyakini Chiou, Huang, dan Lee (2005) merupakan salah satu faktor yang menjadi pengaruh dalam mengkonsumsi produk musik bajakan karena mereka yakin bahwa maraknya perilaku pembajakan dapat menyakiti idola mereka. Namun, hal ini menunjukan hubungan negatif terhadap sikap atas produk musik bajakan. Berdasarkan penjelasan ini, diajukan hipotesis berikut ini:

H2: $\quad$ Singer idolization yang dilakukan konsumen berpengaruh negatif terhadap sikap atas produk musik bajakan

H7 : $\quad$ Singer idolization yang dilakukan konsumen berpengaruh negatif terhadap niat beli atas produk musik bajakan

Dampak risiko yang dirasakan dan filsafat moral yang ditemukan oleh Fraedrich dan Ferrell (1992) pada pembuatan keputusan konsumen yang etis memiliki enam aspek; yaitu keuangan, kinerja, fisik, psikologis, sosial, dan risiko secara keseluruhan. Tetapi Chiou, Huang, dan Lee (2005) berfokus pada alasan-alasan yang mengikuti terhadap pengaruh risiko atas sikap pembajakan musik. Pertama, karena biaya pembelian CD musik bajakan murah yang menjadikan risiko keuangan sangat rendah. Kedua, dengan munculnya era digital, CD bajakan memiliki kualitas hampir sama dengan yang asli sehingga risiko kinerja juga hampir tidak ada. Namun yang paling berpengaruh yaitu risiko sosial yang menimbulkan pelanggaran hak cipta. Cordell et al (1996) dalam Ang et al. (2001) berpendapat bahwa konsumen yang lebih lawful-minded mempunyai kecenderungan yang rendah untuk membeli barang bajakan. Dengan demikian, pengaruh resiko hukum atas konsumsi produk musik bajakan dinilai Chiou, Huang, dan Lee (2005) berpengaruh terhadap sikap atas CD lagu bajakan. Berdasarkan penjelasan ini, diajukan hipotesis berikut ini:

H3 : Prosecution risk pada konsumen berpengaruh negatif terhadap sikap atas produk musik bajakan

Jones (1991) menyatakan bahwa permasalahan moral yang mengenai etika berperilaku seseorang akan memberi efek pada proses pengambilan keputusan. Social consensus adalah salah satu dimensi dari enam yang membentuk perilaku bertindak dengan etis yaitu disebabkan oleh tingkat persepsi masyarakat dalam menilai perilaku mengkonsumsi produk musik bajakan dapat mempengaruhi sikap atas produk musik bajakan. Berdasarkan penjelasan ini, diajukan hipotesis berikut ini:

H4: Social consensus yang dirasakan konsumen berpengaruh negatif terhadap sikap atas produk musik bajakan

Magnitude of consequence adalah seberapa besar konsekuensi yang disebabkan oleh perilaku pembajakan musik terhadap penyanyi, industri musik dan yang lainnya. Apabila penyanyi atau industri musik sudah mengalami kebangkrutan dan tidak dapat 
berproduksi kembali akan berpengaruh langsung terhadap konsumen. Oleh karena itu, magnitude of consequense sebagai salah satu faktor yang dapat mempengaruhi sikap konsumen terhadap CD bajakan yang menyangkut tentang moral (Chiou, Huang, dan Lee :2005). Berdasarkan penjelasan ini, diajukan hipotesis berikut ini:

H5: Magnitude of consequence yang ditimbulkan berpengaruh negatif terhadap sikap atas produk musik bajakan

Perilaku pembajakan musik diyakini Chiou, Huang, dan Lee (2005) juga mempengaruhi terhadap diri konsumen itu sendiri. Seperti dinilai Chia dan Mee (2000) termasuk dalam salah satu dimensi yang mempengaruhi situasi moral. Bagi kebanyakan orang, musik adalah bagian penting dari kehidupan sehingga apabila runtuhnya industri musik akan secara signifikan mempengaruhi kehidupan individu dan secara langsung memepengaruhi sikap konsumen atas produk musik bajakan. Berdasarkan penjelasan ini, diajukan hipotesis berikut ini:

H6: $\quad$ Proximity yang dirasakan konsumen berpengaruh negatif terhadap sikap atas produk musik bajakan

H8: $\quad$ Proximity yang dirasakan konsumen berpengaruh negatif terhadap niat beli atas produk musik bajakan

Sikap terhadap perbuatan, tingkat mana seseorang memiliki evaluasi menguntungkan atau tidak menguntungkan atau penilaian dari perilaku tersebut, biasanya diusulkan menjadi penentu utama dalam niat berperilaku (Ajzen dan Fishbein :1980). Sedangkan (Chiou, Huang, dan Lee (2005) menyatakan bahwa sikap terhadap tindakan adalah sikap umum terhadap pembajakan musik, sedangkan untuk niat perilaku difokuskan pada musik niat pembajakan terhadap fokus konsumen penyanyi idola. Hal ini diyakini bahwa sikap pembajakan musik secara umum akan mempengaruhi niat pembajakan musik secara spesifik. Berdasarkan penjelasan ini, diajukan hipotesis berikut ini:

H9 : $\quad$ Sikap konsumen atas produk musik bajakan berpengaruh positif terhadap niat membeli produk musik bajakan

\section{METODE PENELITIAN}

Penelitian ini merupakan penelitian kuantitatif eksplanatori yang bertujuan untuk menjelaskan pengaruh attribute satisfaction, singer idolization, prosecution risk, social consensus, magnitude of consequence dan proximity terhadap sikap konsumen terhadap produk musik bajakan serta niat konsumen untuk mengkonsumsinya. Populasi dalam penelitian ini adalah konsumen musik Indonesia, dan sampel penelitian ini adalah konsumen musik Indonesia yang pernah membeli atau mengunduh musik bajakan dalam kurun waktu satu tahun terakhir. Instrumen yang digunakan untuk pengumpulan data adalah kuesioner yang disebarkan secara online melalui media sosial Facebook. Karakteristik responden yang terlibat dalam penelitian ini adalah 53,5\% pria, 72\% berusia di bawah 25 tahun, 53\% berstatus mahasiswa, 39\% memiliki pendapatan per bulan Rp 1jt, dan berlatar belakang pendidikan SMA (36,5\%), Diploma (28,5\%), Sarjana (25,5\%), dan sisanya Pascasarjana.

Item pertanyaan di kuesioner diadaptasi dari penelitian Chiou, Huang, dan Lee (2005). Item di kuesioner disajikan dengan menanyakan tingkat kesetujuan responden atas pernyataanpernyataan yang tersaji. Pengukuran dilakukan dengan menggunakan skala Likert 1-4, di mana 1 menunjukkan sangat tidak setuju dan 4 menunjukkan sangat setuju. Penelitian ini sengaja menghilangkan pilihan jawaban netral untuk menghindarkan responden memilih jawaban netral. Hal ini dilakukan mengingat sebagian pertanyaan di kuesioner ini menanyakan nilai-nilai etika yang dianut oleh responden. Pengujian reliabilitas dan validitas menunjukkan bahwa semua item di kuesioner dinilai reliabel dan valid. Untuk menganalisis 
data, menguji hipotesis, dan menguji model penelitian, penelitian ini menggunakan program SPSS versi 18 dan AMOS versi 18.

\section{HASIL DAN PEMBAHASAN}

Pada Tabel 1 terlihat bahwa hasil evaluasi model untuk full model structural modification sudah menunjukkan kriteria yang baik dimana untuk setiap ukuran goodness of fit sudah mencapai angka fit. Dari hasil ini dapat disimpulkan bahwa model struktural yang telah dilakukam modifikasi telah dapat menghasilkan tingkat kebenaran pendugaan yang tinggi. Dengan demikian untuk melakukan pengujian hipotesis penelitian yang diajukan lebih baik apabila menggunakan hasil model struktural yang sudah dimodifikasi.

Tabel 1

Uji Goodness Of Fit Full Model Structural Modification

\begin{tabular}{|c|c|c|c|}
\hline Goodness Of Fit Index & Cut-off Value & Hasil Model & Keterangan \\
\hline RMSEA & $\leq 0,08$ & 0,075 & Baik \\
\hline GFI & $\geq 0,90$ & 0,936 & Baik \\
\hline AGFI & $\geq 0,90$ & 0,91 & Baik \\
\hline CFI & $\geq 0,95$ & 0,973 & Baik \\
\hline TLI & $\geq 0,95$ & 0,962 & Baik \\
\hline NFI & $\geq 0,90$ & 0,943 & Baik \\
\hline Cmin/df & $\leq 0,20$ & 0,18 & Baik \\
\hline
\end{tabular}

Sumber: Data Diolah-Lampiran $x$

Berikut adalah hasil nilai standardized regression weight model persamaan struktural yang telah dimodifikasi:

Tabel 4.27

Standardized Regression Weight Full Model Structural Modification

\begin{tabular}{|c|l|c|c|c|c|}
\hline Hipotesis & \multicolumn{1}{|c|}{ Kausalitas } & $\begin{array}{c}\text { Standardized } \\
\text { Estimate }\end{array}$ & S.E & C.R. & Signifikansi \\
\hline H1 & Attribute Satisfaction -> Sikap & 0,694 & 0,079 & 7,485 & $* * *$ \\
\hline H2 & Singer Idolization -> Sikap & $-0,135$ & 0,071 & $-1,675$ & 0,094 \\
\hline H3 & Prosecution Risk -> Sikap & $-0,021$ & 0,042 &,- 303 & 0,762 \\
\hline H4 & Social Consensus -> Sikap & $-0,120$ & 0,053 & $-1,549$ & 0,121 \\
\hline H5 & $\begin{array}{l}\text { Magnitude Of Consequence } \\
\text {-> Sikap }\end{array}$ & $-0,300$ & 0,069 & $-3,592$ & $* * *$ \\
\hline H6 & Proximity -> Sikap & $-0,181$ & 0,052 & $-2,380$ & 0,017 \\
\hline H7 & Singer idolization -> Niat & $-0,112$ & 0,109 & $-1,505$ & 0,132 \\
\hline H8 & Proximity -> Niat & $-0,104$ & 0,082 & $-1,458$ & 0,145 \\
\hline H9 & Sikap -> Niat & 0,543 & 0,139 & 6,520 & $* * *$ \\
\hline
\end{tabular}

Sumber: Data Diolah-Lampiran $\mathrm{x}$ 


\section{Jurnal Manajemen Teori dan Terapan \\ Tahun 6. No. 3, Desember 2013}

Berdasarkan hasil uji hipotesis yang ada pada tabel 4.27 dapat diketahui bahwa nilai signifikansi untuk pengaruh dari attribute satisfaction terhadap sikap adalah sangat kecil yang nilainya lebih kecil dari 0,05 ( $a=5 \%)$. Hasil ini menyimpulkan bahwa attribute satisfaction pada CD bajakan memiliki pengaruh yang signifikan terhadap sikap. Pengaruh yang besar attribute satisfaction terhadap sikap adalah sebesar 0,694 dengan arah pengaruh positif yang memiliki arti bahwa apabila attribute satisfaction semakin tinggi maka tingkat sikap konsumen terhadap CD musik bajakan akan mengalami peningkatan yang signifikan. Dengan demikian hipotesis pertama terdukung. Apabila konsumen merasa puas atas kualitas yang melekat pada CD musik bajakan maka konsumen cenderung menyukai produk musik bajakan tersebut. Hal ini berbeda dengan penelitian yang dilakukan oleh Chiou, Huang, dan Lee (2005) yang mengacu pada atribut kepuasan CD musik asli sebagai faktor yang dapat mempengaruhi sikap konsumen terhadap CD musik bajakan.

Berdasarkan hasil uji hipotesis yang ada pada tabel 4.27 dapat diketahui bahwa nilai signifikansi untuk pengaruh dari singer idolization terhadap sikap adalah sebesar 0,094 yang nilainya lebih besar dari 0,05 (a=5\%). Hasil ini menyimpulkan bahwa singer idolization yang dirasakan konsumen berpengaruh tidak signifikan terhadap sikap pada CD musik bajakan. Dengan demikian hipotesis kedua tidak terdukung. Tidak signifikannya pengaruh singer idolization terhadap sikap konsumen atas CD musik bajakan ini disebabkan oleh beberapa responden tidak mengidolakan artis penyanyi / grup band idolanya dengan loyal.

Selain itu, nilai signifikansi masing-masing untuk pengaruh prosecution risk dan social consensus terhadap sikap pada CD musik bajakan adalah sebesar 0,762 dan 0,121 yang nilainya lebih besar dari 0,05 (a=5\%). Hasil ini juga menyimpulkan bahwa prosecution risk dan social consensus yang dirasakan konsumen berpengaruh tidak signifikan terhadap sikap pada CD musik bajakan. Dengan demikian hipotesis ketiga dan keempat tidak dapat diterima. Tidak signifikannya pengaruh prosecution risk terhadap sikap konsumen atas $C D$ musik bajakan ini disebabkan oleh beberapa responden yang tidak mempedulikan hukum yang berlaku. Selain itu, hasil pengujian hipotesis keempat $(\mathrm{H} 4)$ diketahui pula bahwa konsensus sosial yang berlaku di lingkungan konsumen tidak terbukti memiliki pengaruh yang negatif terhadap sikap konsumen karena hasil yang tidak signifikan. Tidak signifikannya pengaruh social consensus terhadap sikap konsumen atas CD musik bajakan ini disebabkan oleh beberapa responden yang menghiraukan konsensus atau norma sosial yang berlaku di masyarakat.

Nilai signifikansi masing-masing untuk pengaruh dari magnitude of consequences dan proximity terhadap sikap pada CD musik bajakan adalah sangat kecil dengan nilai yang lebih kecil dari 0,05 ( $a=5 \%)$. Hasil ini menyimpulkan bahwa magnitude of consequences dan proximity yang dirasakan konsumen memiliki pengaruh yang signifikan terhadap sikap pada CD musik bajakan. Besar pengaruh masing-masing magnitude of consequences dan proximity terhadap sikap adalah sebesar $-0,300$ dengan arah pengaruh negatif yang memiliki arti bahwa apabila magnitude of consequences dan proximity semakin tinggi maka tingkat sikap konsumen terhadap CD musik bajakan akan mengalami penurunan yang signifikan. Dengan demikian hipotesis kelima dan keenam dapat diterima. Apabila konsumen merasa bahwa akan berdampak negatif kepada pelaku industri musik jika mengkonsumsi produk musik bajakan maka sikap konsumen terhadap produk musik bajakan tersebut akan tidak suka. Hasil ini konsisten dengan temuan dari penilitian Chiou, Huang, dan Lee (2005) yang menyatakan bahwa konsumen yang peduli terhadap dampak negatif yang akan dirasakan pelaku industri musik akibat produk musik bajakan (magnitude of concequences) akan bersikap negatif terhadap produk musik bajakan tersebut. Selain itu, apabila konsumen merasa bahwa akan berdampak negatif kepada diri sendiri jika mengkonsumsi produk musik bajakan maka sikap konsumen terhadap produk musik bajakan tersebut akan tidak suka. Hasil ini pula konsisten dengan temuan dari penilitian Chiou, Huang, dan Lee (2005) yang menyatakan bahwa konsumen yang peduli terhadap dampak negatif yang akan dirasakan dirinya sendiri akibat produk musik bajakan (proximity) akan bersikap negatif terhadap produk musik bajakan tersebut. 


\section{Sony Kusumasondjaja \\ Nazar Kharisma}

Sedangkan, nilai signifikansi untuk masing-masing pengaruh singer idolization dan proximity terhadap niat beli pada CD musik bajakan adalah sebesar 0,132 dan 0,145 yang nilainya lebih besar dari 0,05 (a=5\%). Hasil ini juga menyimpulkan bahwa singer idolization dan proximity yang dirasakan konsumen berpengaruh tidak signifikan terhadap niat beli pada CD musik bajakan. Dengan demikian hipotesis ketujuh dan kedelapan tidak dapat diterima. Tidak signifikannya pengaruh singer idolization terhadap niat beli konsumen atas CD musik bajakan ini disebabkan oleh beberapa responden yang tidak begitu menggemari artis penyanyi favoritnya. Sementara itu, tidak signifikannya pengaruh proximity terhadap sikap konsumen atas CD musik bajakan ini disebabkan oleh beberapa responden yang menghiraukan konsensus atau norma sosial yang berlaku di masyarakat. Seiring dengan adanya penilaian terhadap sikap konsumen terhadap CD musik bajakan, maka akan muncul niat pembelian.

Nilai signifikansi untuk pengaruh dari sikap terhadap niat beli $C D$ musik bajakan adalah sangat kecil yang nilainya lebih kecil dari 0,05 ( $a=5 \%)$. Hasil ini menyimpulkan bahwa sikap pada CD bajakan memiliki pengaruh yang signifikan terhadap niat beli. Pengaruh yang besar sikap terhadap niat beli adalah sebesar 0,694 dengan arah pengaruh positif yang memiliki arti bahwa apabila sikap konsumen semakin tinggi maka tingkat niat beli terhadap CD musik bajakan akan mengalami peningkatan yang signifikan. Dengan demikian hipotesis kesembilan dapat diterima.

Temuan lain yang cukup menarik adalah diperoleh hasil bahwa responden dengan jenis perempuan cenderung memiliki tingkat ketidakkhawatiran lebih rendah terhadap dampak negatif yang akan dirasakan pelaku industri musikdibanding dengan responden berjenis kelamin laki-laki. Responden dengan usia 35 - 44 tahun cenderung lebih memiliki tingkat pengidolaan pada penyanyi favorit dibanding kategori usia yang lain. Selain itu, responden dengan usia 35 - 44 tahun juga memiliki tingkat kepedulian lebih tinggi terhadap dampak negatif yang ditimbulkan akibat CD musik bajakan dari kategori usia responden lainnya. Kemudian responden dengan pendidikan terakhir SMA cenderung lebih memiliki tingkat khawatiran lebih tinggi pada resiko hukum dibanding kategori pendidikan yang lain. Hasil temuan tersebut menunjukkan bahwa faktor jenis kelamin, usia, dan pendidikan memiliki kontribusi terhadap respon konsumen dalam konteks konsumsi CD musik bajakan.

\section{SIMPULAN}

Berdasarkan dari hasil analisis data, penelitian ini menyimpulkan bahwa atribut kepuasan (attribute satisfaction) pada CD musik bajakan memiliki pengaruh positif yang signifikan terhadap sikap konsumen atas CD musik bajakan tersebut. Namun, pengidolaan penyanyi (singer idolization), resiko hukum (prosecution risk), dan konsensus sosial (social consensus) konsumen tidak berpengaruh terhadap sikap konsumen atas CD musik bajakan. Sementara itu, besarnya konsekuensi (magnitude of consequences) dan efek pada diri sendiri (proximity) yang ada pada persepsi konsumen memiliki pengaruh negatif yang signifikan terhadap sikap konsumen atas CD musik bajakan. Pengidolaan penyanyi (singer idolization) dan efek pada diri sendiri (proximity) konsumen tidak berpengaruh terhadap niat beli konsumen atas CD musik bajakan. Sikap konsumen pada CD musik bajakan memiliki pengaruh positif yang signifikan terhadap niat beli konsumen pada CD musik bajakan.

Penelitian ini berkontribusi dalam memberikan konfirmasi mengenai bagaimana model penelitian diaplikasikan di Indonesia, mengingat bahwa penelitian sebelumnya dilakukan di wilayah negara lain. Dalam penelitian ini diperoleh temuan yang menarik, yaitu terdapat perbedaan respon konsumen terhadap produk musik bajakan pada jenis kelamin responden, usia, dan pendidikan terakhir. Berdasarkan hasil penelitian ditemukan bahwa perempuan cenderung memiliki tingkat ketidakkhawatiran lebih rendah terhadap dampak negatif yang akan dirasakan pelaku industri musikdibanding dengan responden berjenis kelamin laki-laki. Responden dengan usia 35 - 44 tahun cenderung lebih memiliki tingkat pengidolaan pada penyanyi favorit dibanding kategori usia yang lain. Selain itu, responden dengan usia 35 - 44 tahun juga memiliki tingkat kepedulian lebih tinggi terhadap dampak 


\section{Jurnal Manajemen Teori dan Terapan \\ Tahun 6. No. 3, Desember 2013}

negatif yang ditimbulkan akibat CD musik bajakan dari kategori usia responden lainnya. Kemudian responden dengan pendidikan terakhir SMA cenderung lebih memiliki tingkat khawatiran lebih tinggi pada resiko hukum dibanding kategori pendidikan yang lain. Namun dalam penelitian ini temuan tersebut tidak dibahas secara mendalam karena bukan fokus utama penelitian ini. Hasil tersebut dapat menjadi kontribusi yang dapat digunakan sebagai pijakan awal untuk penelitian selanjutnya.

Faktor-faktor yang menjadi ancaman industri musik salah satunya adalah masih maraknya CD musik bajakan sebagai barang alternatif terhadap pemenuhan kebutuhan musik konsumen. Sehingga kepuasan konsumen telah terpenuhi dengan mengkonsumsi CD bajakan tanpa harus membeli CD musik yang asli. Oleh karena itu, perlu diperhatikan cara memasarkan produk musik asli yang lebih baik sehingga konsumen dapat mengetahui kualitas yang diberikan. Selain itu, faktor moral dan rasa sosial konsumen terhadap pelaku industri musik juga dapat menjadi acuan untuk mengetahui apa yang masih mempengaruhi konsumen untuk mengkonsumsi CD musik bajakan.

Hasil temuan dalam penelitian ini dapat membantu memberikan informasi mengenai faktor-faktor apa saja yang mempengaruhi konsumen untuk mengkonsumsi CD musik bajakan. Diharapkan hasil penelitian ini dapat menjadi bahan pertimbangan pelaku industri musik dan pemerintah atau lembaga terkait pembajakan untuk menekan perilaku mengkonsumsi produk musik bajakan di Indonesia ini.

\section{REFERENSI}

Aaker, David, V. Kumar dan George S. Day. 1998. Marketing Research. $6^{\text {th }}$ Edition. New York: John Wiley and Sons.

Ajzen, I. and M. Fishbein. 1980. Understanding Attitudes and Predicting Social Behavior. New Jersey: Prentice Hall.

1977. Attitude-Behavior Relations: A Theoretical Analysis and Review of Empirical Research. Psychology Bulletin, Vol. 84, pp. 888-918.

Anderson, J. C. and D. W. Gerbing. 1988. Structural Equation Modeling in Practice: A Review and Recommended Two-Step Approach. Psychological Bulletin, 103, 411.

Ang, S. H. Cheng, P. S., Lim, E. A. C. dan Tambyah, S. K. 2001. Spot The Difference: Consumer Responses Towards Counterfeits. Journal of Consumer Marketing, 18(3): 219-235.

Assael, Henry. 2001. Consumer Behavior. $6^{\text {th }}$ Edition. New York: Thomson Learning.

Bolton, R. N. and K. N. Lemon. 1999. 'A Dynamic Model of Customers' Usage of Services: Usage as an Antecedent and Consequence of Satisfaction'. Journal of Marketing Research36. 171186.

Bower AB, Landreth, S. 2001. Is beauty best? Highly Versus Normally Attractive Models In Advertising. Journal of Advertising., 30(1): 1-12.

Bungin, Burhan.. 2008. Metodologi Penelitian Kuantitatif (Komunikasi, Ekonomi, dan Kebijakan Publik Serta IImu-IImu Sosial Lainnya). Jakarta: Kencana Prenada Media Grup.

Chiou, J.-S., C.-Y. Huang and H.-H. Lee. 2005. The Antecedents of Music Piracy And Intentions. Journal of Business Ethic 57(2): 161-174. 
Cordell, V. V, Wongtada, N. and Kieschnick, R. L. Jr. 1996. Counterfeit Purchase Intentions: Role of Lawfulness Attitudes and Product Traits as Determinants. Journal of Business Research, Vol. 35, pp. 41-53.

De Matos, C. A., Ituassu, C. T. and Rossi, C. A. V.. 2007. Consumer Attitudes Toward Counterfeits: A Review and Extention. Journal of Marketing, Vol. 24 No. 1, pp. 36-47.

Ferdinand, Agusty. 2006. Structural Equation Modeling Dalam Penelitian Manajemen. Edisi Keempat. Semarang: Badan Penerbit Universitas Diponegoro.

Fraedrich, J. P. and O. C. Ferrell .1992. The Impact of Perceived Risk and Moral Philosophy Type on Ethical Decision Making in Business Organizations. Journal of Business Research 24, 283-295.

Ghozali, I. 2009. Aplikasi Analisis Multivarian dengan Program SPSS. Semarang: Badan Penerbit Undip.

Grab Statistic. 2013. http://www.grabstats.com diakses pada 9 Desember 2012

Hair et al., 1998. Multivariate Data Analysis. Fifth Edition, Prentice Hal, Upper Saddle River: New Jersey.

Hidayat, A. dan Mizarski. 2005. Pembajakan Produk: Problema, Strategi dan Antisipasi Strategi. Jurnal Siasat Bisnis, 1(10): 95-122.

Indrianto, N. dan Supomo, B. 1999. Metodologi Penelitian Bisnis untuk Akuntansi dan Manajemen. Edisi Pertama. Yogyakarta: Erlangga.

Jones, T. M.. 1991 Ethical Decision Making By Individuals in Organizations: An Issue-Contingent Model. Academy of Management Review16(2): 366-395.

Kompas. 2013. http://www.kompas.com diakses pada 13 Desember 2012

Kotler, P. dan K. L. Keller. 2009. Manajemen Pemasaran I. Edisi ketigabelas. Jakarta: Erlangga. Hall.

Lai, K. Ka-Yuk dan Judith L. Z. 1999. Brand Imitation: Do the Chinese Have Different Views. Asia Pacific Journal of Management, 16 (2): 179-92.

Levitt, T. 1966. Innovative Imitation. Hardvard Business Review. (9-10): 63.

Malhotra, N. K. 2007. Marketing Research: An Applied Orientation. New Jersey: Pearson Eduction, Inc, Prentice Hall.

Mowen, John. C. dan Michael Minor. 2002. Perilaku Konsumen. Jilid Dua. Edisi Kelima Terjemahan. Jakarta: Erlangga. 
Peter, Paul J. \& C. Olson. 2005. Consumer Behavior and Marketing Strategy. Seventh Edition. Singapore: Mc Graw Hill.

Phau, Ian dan James Ng. 2009. Predictors of Usage Intentions of Pirated Software. Journal of Business Ethics. 94:23-37.

Puspitha, Gita Swarga. 2009. Hubungan Emosional dan Loyalitas Pada Penggemar Grup Musik Slank Di Surabaya. Skripsi. Surabaya: Unair.

Raviv, A., D. Bar-Tal, A. Raviv and A. Ben-Horin. 1996. Adolescent Idolization of Pop Singers: Causes, Expressions, and Reliance. Journal of Youth and Adolescence 25(5), 631-650.

Shamdasani, P. N., Satanaland, A.J.S., \& Tan, J. 2001. Location, location, location: Insights for Advertising Placement On The Web. Journal of Advertising Research, 41 (4), 7-21.

Schiffman, L. G. and Kanuk, L., (2004), Consumer Behavior. International Edition. New Jersey: Prentice Hall Inc.

Sekaran, Uma. 2003. Research Methods for Business: A Skill Building Approach $4^{\text {th }}$ Edition. United Stated of America: John Wiley \& Son, Inc.

Solimun. (2002). Structural Equation Modeling LISREL dan Amos. Fakultas MIPA Universitas Brawijaya, Malang.

Wang, F., et al., 2005. Purchasing Pirated Software: An Initial Examination of Chinese Consumers. Journal of Consumer Marketing, Vol. 22 No. 6. Pp. 340-551.

Wells, William, John Burnet and Sandra Moriarty. 2003. Advertising Principle and Practice. Fifth Edition. New Jersey: Prentice Hall International, Inc. 